\title{
PEMANFAATAN TEKNOLOGI PENGELOLAAN OPT TANAMAN SAYURAN BERBAHAN BAKU RAMAH LINGKUNGAN DI KANAGARIAN PANINJAUAN KABUPATEN TANAH DATAR
}

\author{
Ujang Khairul $^{2)}$, Reflin $^{2)}$, Arneti ${ }^{2)}$
}

\begin{abstract}
Activity of use management technologogy for pest and plant disease control on vegetables based environment friendly in nagari Paninjauan Kabupaten Tanah Datar has been carried out from June to November 2014. This activity aims to improve farmers knowledge about the diseases attack of vegetables and know how to manage the disease using biopesticide and botanic biopesticide,

These activities include: Counseling and training, and evaluation. Results of monitoring the level of disease in vegetable crops is known that those plants attacked by pest and pathogens e.i, soft rot (cabbage), anthracnosa, bacterial wilt and leaf spot (chili), tuber rot ( carrots) and bacterial leaf blight and Alternaria spots (onion leaves). Attack rate ranged between $16-20 \%$ for disease and $15-$ $30 \%$ for pest. From the activities can be take several conclusions: (1) Extent of disease in vegetable crops in this area is high, (2) The farmers do not yet understand the causes of pest and plant disease (pathogens) that attack their vegetable crops, (3) The farmers do not understand the methods of disease control using biopesticide and botanic biopesticide, (4) The extension and field practice, have improved farmers' knowledge about the management of vegetable diseases using biopesticides and botanic biopesticide
\end{abstract}

Key word : Vegetatable crops, biopesticide, botanic biopesticide,Paninjauan

1. Dibiayai Dana DIPA- Kompetitif Unand Tahun 2014

2. Staf Pengajar Jurusan HPT Fakultas Pertanian Universitas Andalas

\section{PENDAHULUAN}

Kanagarian Paninjauan Kecamatan X Koto merupakan salah satu kanagarian di Kabupaten Tanah Datar yang menjadi daerah sentra produksi sayuran. Luas areal sayuran di kanagarian ini mencapai $521 \mathrm{Ha}$ dengan produktivitas 435,5 ton/ha/th. Setiap tahun terjadi peningkatan luas pertumbuhan sayuran mencapai $10.2 \%$. Sekitar 30-60\% dari produk sayuran ini setiap hari di kirim ke daerah tetangga seperti Riau, Jambi dan Bengkulu dan juga diekspor ke Singapura dan Malaysia (Bappeda Kabupaten Tanah Datar, 2013). 
Dalam mengusahakan tanamannya, petani selalu dihadapkan dengan beberapa masalah yang membatasi usaha peningkatan produksi, salah satunya adalah serangan OPT. Untuk mengendalikan OPT petani sayuran di daerah ini rutin menggunakan pestisida sintetis seperti insektisida, fungisida dan bakterisida. Biaya yang dikeluarkan untuk pembelian pestisida mencapai 25\% dari biaya produksi (Dinas Pertanian Perkebunan dan Kehutanan Kabupaten Tanah Datar, 2013). Ratarata petani sayuran menyemprot tanamannya dengan interval 5 - $6 \mathrm{kali} / \mathrm{minggu}$, tidak sedikit petani yang menyemprot lebih pendek dari pada interval tersebut, terutama apabila turun hujan.

Praktek penggunaan pestisida sintesis yang intensif dan tidak bijaksana dan tanpa mempertimbangkan keseimbangan ekologis dan ekonomi akan memunculkan banyak efek yang merugikan diantaranya: tingginya biaya produksi, timbulnya resistensi, resurjensi dari Organisme Pengganggu Tumbuhan (OPT).

Sesuai dengan program pertanian berkelanjutan yang diterapkan di Indonesia maka teknik pengendalian Organisme Pengganggu Tumbuhan (OPT) pada tanaman sayuran harus mengacu pada Pengendalian Hama dan Hama dan penyakit secara Terpadu (PHT). Salah satu komponen utama dari program PHT adalah pengendalian hayati dengan memanfaatkan agensia pengendalian hayati (biopestisida).

Bertitik tolak dari permasalahan di atas dan dari hasil-hasil penelitian sebelumnya yang dilakukan oleh tim pelaksana kegiatan telah didapatkan beberapa biopestisida yang telah diformulasi dengan menggunakan bahan amendeman berupa limbah air kelapa, ampas tebu, dedak dan tepung tapioka. Biopestisida ini dapat digunakan sebagai pengganti pestisida sintetis untuk pengelolaan beberapa OPT yang sering menyerang tanaman sayuran petani di daerah ini. Kegiatan ini dimaksudkan guna pengentasan kemiskinan melalui kemandirian petani dalam menyediakan sarana produksi, meningkatkan ketersedian produk sayuran melalui kegairahan dan kesungguhan dalam budidaya tanaman hortikultura umumnya dan sayuran khususnya, peningkatan nilai jual produk sayuran dengan komoditi ramah lingkungan dan aman dikonsumsi.

Pada bulan Februari 2014, tim pengusul telah melakukan penjajakan kepada mitra yaitu kelompok tani sayuran Suduik Sepakat Jorong Tigo Suku Nagari 
Paninjauan Kecamatan X Koto Kabupaten Tanah Datar. Penjajakan dilakukan untuk melihat kondisi dan potensi lokal yang dimiliki mitra dan sinergisnya dengan kebijakan pemerintah daerah. Setelah didiskusikan dengan mitra. beberapa masalah yang berhasil diidentifikasi adalah sebagai berikut: (1) Adanya serangan OPT yang menyerang tanaman sayuran mitra, (2) Mitra masih menggunakan pestisida sintetis sebagai alternatif utama untuk mengendalikan OPT yang menyerang tanaman sayuran mereka.

\section{METODE PELAKSANAAN}

Metode yang digunakan dalam kegiatan ini adalah sebagai berikut:

Survey Pendahuluan dan Pendekatan Sosial. Tahap ini bertujuan untuk melakukan komunikasi dan sosialisasi maksud dan tujuan kegiatan program pengabdian kepada masyarakat melalui ketua kelompok tani mitra. Dari kegiatan ini diharapkan terciptanya suatu kerjasama antara masyarakat, unit pengelola penyuluhan berbasis petani dan aparat pemerintah. Selain itu, kegiatan ini akan memperoleh legitimasi bagi semua kegiatan yang berkaitan dengan pelaksanaan program pengabdian kepada masyarakat, sehingga dukungan semua pihak dapat diperoleh. Masyarakat bersedia untuk mengikuti kegiatan ini serta menyediakan waktu

Sosialisasi dan Penyuluhan. Tim pelaksana kegiatan dengan anggota kelompok petani berkumpul di ruang pertemuan kelompok tani Suduik Sepakat Jorong Tigo Suku Nagari Paninjauan Kecamatan X Koto Kabupaten Tanah Datar. Kegiatan ini bertujuan untuk memberikan materi penyuluhan berupa :

a. OPT yang sering menyerang tanaman sayuran

b. Dampak negatif penggunaan pestisida sintetik yang intensif dan tidak bijaksana dalam pengendalian OPT

c. Pemanfatan biopestisida,pestisida botani dalam pengendalian OPT tanaman sayuran.

d. Pengenalan cara pembuatan, perbanyakan dan penggunaan biopestisida,pestisida botani 
Praktek. Praktek yang dilaksanakan bertujuan untuk menambah wawasan dan pengetahuan petani tentang pembuatan biopestisida,pestisida botani yang bahan bakunya ada di alam. Praktek dilakukan pada semua anggota kelompok tani mitra. Kegiatan penyuluhan, diskusi dan praktek dilakukan 1 hari penuh.

Rancangan Evaluasi. Melakukan evaluasi berupa pre test yang dilakukan sebelum kegiatan dan post test setelah pelaksanaan kegiatan.

\section{HASIL DAN PEMBAHASAN}

Pemantauan serangan OPT di lahan sayuran mitra. Hasil pemantauan terhadap tingkat serangan OPT pada tanaman sayuran yang dilakukan sebelum kegiatan penyuluhan memperlihatkan bahwa sebahagian besar tanaman sayuran yang diusahakan oleh kelompok tani ini seperti; kubis, cabai, dan bawang daun terserang oleh OPT seperti: penyakit busuk basah, dan akar gada (kubis), antraknosa, layu bakteri dan bercak daun (cabai), busuk umbi (wortel) dan hawar daun bakteri serta bercak alternaria (bawang daun). Tingkat serangan hama pada tanaman sayuran di kelompok tani ini berkisar antara 15-30\%, sedangkan serangan patogen penyebab penyakit antara 16-20\%. (Tabel 1 dan Gambar 1). Hama yang ditemukan adalah : Lalat penggorok daun (Liriomyza huidobrensis), ulat gerayak (Spodoptera litura) ulat kubis (Plutella xylostella), kutu daun (Myzus persicae) dan Lalat buah (Trips sp) (Gambar 2). Untuk mengatasi OPT ini, anggota kelompok tani selalu mengandalkan penggunaan pestisida sintetis (bakterisida, fungisida dan insektisida) yang intensitas penyemprotan cukup tinggi yakni setiap 3 hari, apabila sering hujan menjadi setiap 1 -2 hari.

Tabel 1. Jenis OPT yang menyerang tanaman sayuran di lahan kelompok tani Suduik Sepakat

\begin{tabular}{|c|c|c|c|}
\hline No & Jenis Sayuran & Hama*) & Penyakit*) \\
\hline 1 & Kubis & $\begin{array}{l}\text { 1. Crocidolomia binotalis } \\
\text { 2. Plutella xylostella }\end{array}$ & $\begin{array}{l}\text { 1. Busuk basah } \\
\text { 2. Akar gada }\end{array}$ \\
\hline 2 & Bawang daun & $\begin{array}{l}\text { 1. Ulat gerayak } \\
\text { Spodoptera exigua }\end{array}$ & $\begin{array}{l}\text { 1. Bercak daun bakteri } \\
\text { 2. Bercak daun altenaria }\end{array}$ \\
\hline 3 & cabai & $\begin{array}{l}\text { 1. Kutu daun (Myzus } \\
\text { persicae) } \\
\text { 2. Ulat gerayak }\end{array}$ & $\begin{array}{l}\text { 1. Antraknosa (C.capsisi) } \\
\text { 2. Layu bakteri }(R . \\
\text { solanacarum })\end{array}$ \\
\hline
\end{tabular}




\begin{tabular}{|l|l|c|l|}
\hline & $\begin{array}{c}\text { (Spodoptera litura) } \\
\text { 3. Lalat buah (Trips sp) }\end{array}$ & $\begin{array}{l}\text { 3. Bercak daun } \\
\text { (X.a.pv.visicatoria) }\end{array}$ \\
\hline & & & \\
\hline
\end{tabular}

*) dokumentasi hama dan patogen penyebab penyakit terlampir
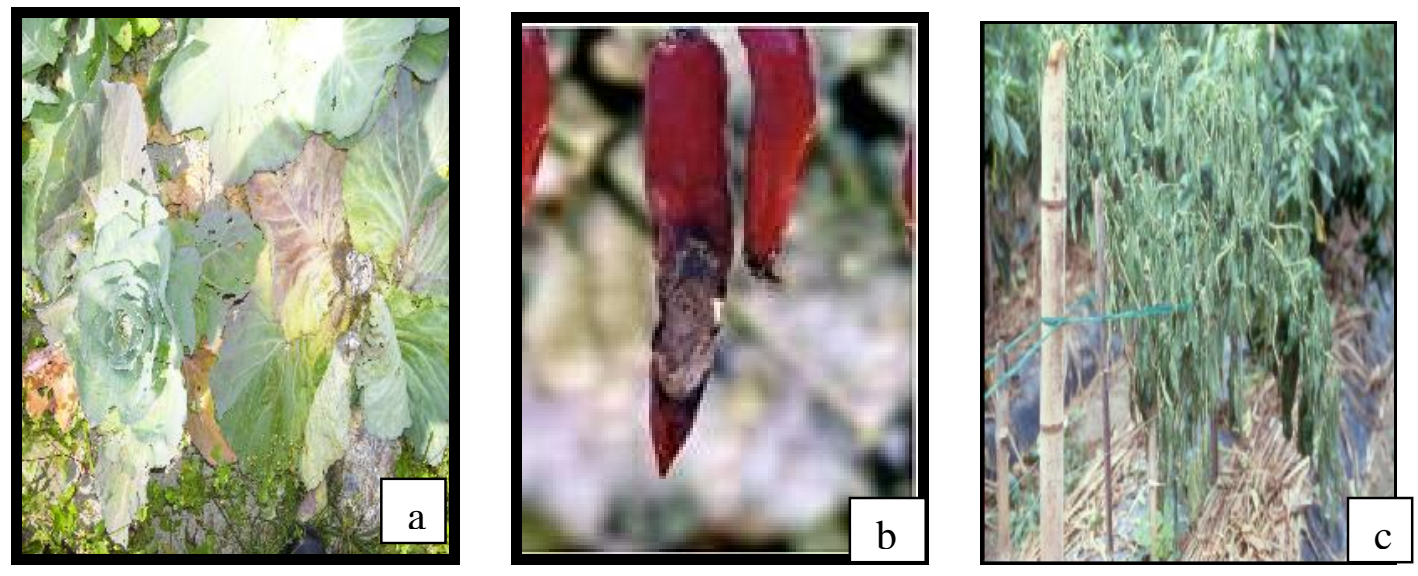

Gambar 1. Beberapa penyakit yang menyerang tanaman sayuran petani di lapangan (a) busuk lunak pada kubis, (b) antraknosa pada cabai dan (c) layu bakteri pada cabai
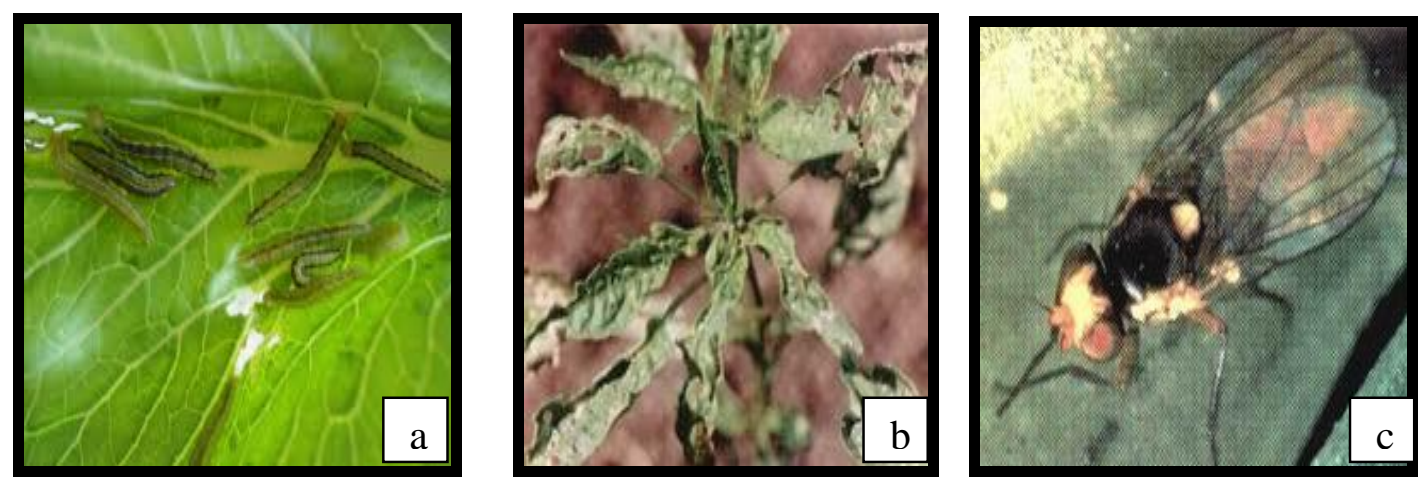

Gambar 2. Beberapa hama yang menyerang tanaman sayuran petani di lapangan (a), Plutella xylostella, (b) kutu daun dan (c) lalat buah

\section{Pengenalan dan diskusi tentang OPT utama yang menyerang tanaman}

sayuran. Sebahagian besar anggota kelompok tani belum mengenal OPT yang menyerang sayuran yang mereka usahakan. Dari hasil pre-test yang dilakukan sebelum kegiatan pengenalan hama dan penyakit yang menyerang sayuran, $82 \%$ peserta tidak mengetahui jenis OPT yang menyerang sayuran. Anggota kelompok tani ini belum bisa membedakan tanaman yang terserang bakteri, jamur atau virus. 
Setelah dikenalkan dengan gejala-gejala serangan hama dan penyakit, anggota kelompok tani mulai dapat membedakan jenis-jenis OPT yang menyerang sayuran mereka.

Dari hasil diskusi dengan anggota kelompok tani diketahui bahwa anggota kelompok tani menggunakan pestisida sintetik untuk mengendalikan OPT pada sayuran, sebahagian besar pestisida-pestisida yang digunakan belum tepat jenis dan sasarannya. Kadang-kadang pestisida sintetik ini dicampurkan satu sama lainnya, padahal ada pestisida yang bahan aktifnya sama sehingga dari sisi analisa usaha tani, hal seperti ini akan meningkatkan biaya tani (modal).

Praktek pembuatan pestisida hayati (biopestisida), pestisida nabati. Dalam kegiatan ini anggota kelompok tani dilatih untuk membuat pestisida hayati, pestisida nabati berbahan baku lokal. Untuk pembuatan pestisida hayati digunakan Trichoderma harzianum, Pseudomonas flourescens dan Bacillus sp.

T.harzianum diperbanyak dengan menggunakan dengan sekam, jerami padi, dan ampas tebu steril, Pseudomonas flourescens dan Bacillus sp. Diperbanyak dengan menggunakan air kelapa dan tepung tapioka steril, Pestisida nabati dibuat dengan menggunakan bahan baku lokal seperti: akar tuba,daun dan bunga kipait, daun sirsak. Bahan-bahan ini ditumbuh/digiling dan diperas, air perasan digunakan untuk pengendalian OPT

Dari kegiatan yang dilakukan terlihat anggota kelompok tani sangat antusias untuk mengikuti kegiatan ini, hal ini terlihat dari aktifitas mereka dalam melakukan diskusi dan tingkat kehadiran yang mencapai $100 \%$. Sebahagian besar anggota mitra belum mengetahui pengendalian OPT dengan memanfaatkan bahan-bahan alam yang ada disekitar mereka, anggota mitra selalu menggunakan pestisida sintetil untuk mengedalikan OPT yang ada pada sayuran mereka. Penggunaan pestisida sintetis yang tidak bijaksana (sangat intensif) akan menimbulkan beberapa dampak yang membahayakan diantaranya: menimbulkan ketahanan pada hama dan penyebab penyakit /patogen (resistensi),mahal, mencemari lingkungan, membunuh mahkluk lain yang bermanfaat

Sesuai dengan program pertanian berkelanjutan yang diterapkan di Indonesia maka teknik pengendalian Organisme Pengganggu Tumbuhan (OPT) harus mengacu pada Pengendalian Hama dan Penyakit secara Terpadu (PHT). Salah satu komponen 
utama dari program PHT adalah pengendalian hayati, yaitu menggunakan mikroorganisme untuk mengendalikan hama dan patogen penyebab penyakit. Keuntungan penggunaan agensia hayati antara lain: ramah lingkungan, berkesinambungan, kesesuaian ekologis, dan dapat diintegrasikan dalam program PHT serta dapat diperbanyak dengan teknologi yang sederhana dan mudah cara aplikasinya.

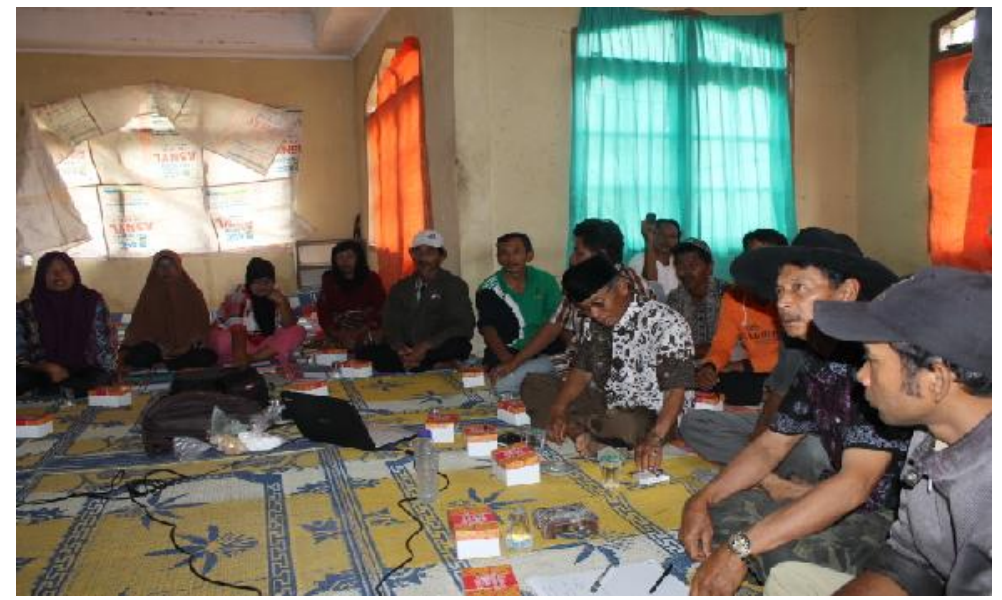

Ketua kelompok tani Mitra membuka acara penyuluhan

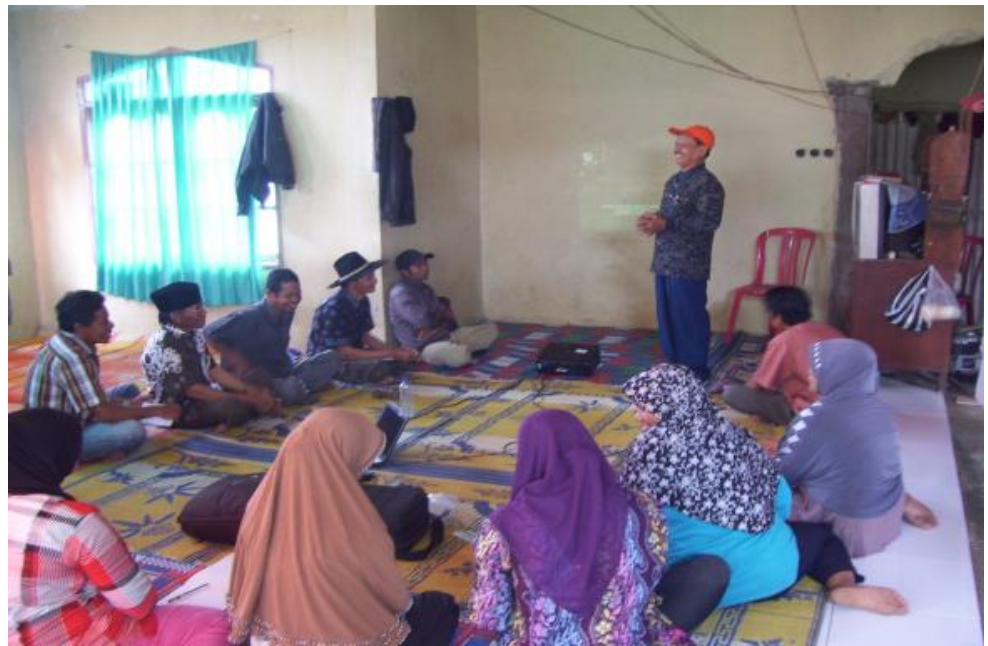




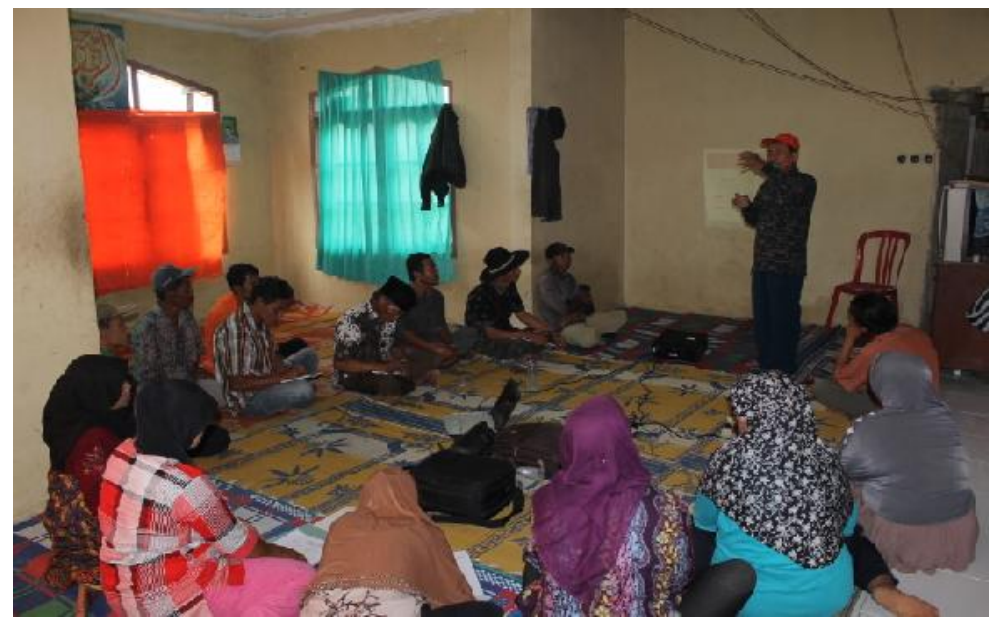

Peserta kegiatan mendengarkan materi yang disampaikan oleh tim

\section{KESIMPULAN DAN SARAN}

Dari kegiatan pengabdian yang telah dilakukan dapat diambil beberapa kesimpulan: (1) Tingkat serangan OPT pada tanaman sayuran di lahan mitra daerah ini cukup tinggi, (2) Sebahagian besar anggota mitra belum memahami OPT yang menyerang tanaman sayuran mereka, (3) Sebahagian besar anggota mitra belum memahami metode pengendalian penyakit pada tanaman sayuran, terutama pengendalian dengan menggunakan biopestisida, pestisida hayati, (4) Adanya praktek telah meningkatkan pengetahuan petani tentang pengelolaan OPT sayuran menggunakan biopestisida dan pestisida nabati

Dari hasil yang didapat dalam pelaksanaan pengabdian, disarankan agar penyuluhan dan pelatihan semacam ini dapat terus berlanjut atau dilakukan dalam waktu yang agak panjang sehingga petani sayuran dapat mengurangi pestisida sintetik yang selama ini selalu digunakan dalam pengendalian OPT.

\section{UCAPAN TERIMA KASIH}

Terima kasih kami ucapkan kepada Lembaga Penelitian Pengabdian Kepada Masyarakat Universitas Andalas yang telah menyediakan dana sehingga kegiatan pengabdian masyarakat berbasis kompetitif ini dapat terlaksana. Kepada segenap Aparat Nagari Paninjauan Kabupaten Tanah Datar yang telah membantu pelaksanaan dan kelancaran kegiatan ini, diucapkan terima kasih. 


\section{Daftar Pustaka}

Arneti. 2004. Penerapan penggunaan insektisida nabati untuk pengendalian hama Spodoptera exigua pada tanaman bawang merah di Nagari Sungai Puar Kecamatan Banuhampu Sungai Puar, Sumatera Barat. Dana Proyek Peningkatan Universitas Andalas. Padang tahun 2004

Bappeda Kabupaten Tanah Datar. 2013. Laporan Kegiatan Dinas Pemerintah Daerah Kabupaten Tanah Datar tahun 2012. Badan Perencanaan dan Pembangunan Daerah Kabupaten Tanah Datar.

Dinas Pertanian, Perkebunan dan Kehutanan Kabupaten Tanah Datar. 2013. Laporan serangan OPT di Kabupaten Tanah Datar. Laporan Tahunan Dinas Pertanian Perkebunan dan Kehutanan Kabupaten Tanah Datar.

Habazar.,T, Rivai.F, Husein E.F. 2001. Pemanfaatan Pseudomonas flourescens sebagai agens penginduksi ketahanan tanaman. Jurnal manggaro, Vol.7 (2): 512

Khairul.U, Winarto, 2005. Analisis Keragaman Molekuler Bacillus subtilis dengan Teknik RAPD (Random Amplified Polymorphic DNA) dan Studi Potensi Antagonisnya Terhadap Ralstonia solanacearum (E.F.Smith) Yabuuchi et al Penyebab Hama dan penyakit Layu Pada Tanaman Cabai. Laporan Penelitian Dasar. Lembaga Penelitian Unand. Padang

Khairul.U, Reflin. 2008. Kajian Fisiologis dan Molekular Streptomyces sp serta Potensi Biokontrolnya Terhadap Ralstonia solanacearum (E.F.Smith) Yabuuchi Penyebab Hama dan penyakit Layu Pada Tanaman Pisang. Laporan Penelitian Dirjen DIKTI. Jakarta

Khairul.U dan Aswaldi Anwar, 2013. Pengembangan Formula Biopestisida Menggunakan Bahan Organik untuk Pengelolaan Penyakit Layu dan Hawar Daun Stewart Pada Tanaman Jagung. Laporan Penelitian Unggulan Perguruan Tinggi. Dirjen DIKTI. Jakarta

Semangun. H. 2000. Hama dan penyakit -hama dan penyakit tanaman hortikultura di Indonesia. Gajah mada University Press. Yokyakarta. 